\title{
QUASI-STATIC MECHANICAL PROPERTIES OF COCONUT SHELL OF DEHUSKED MATURE NUTS
}

by

\author{
E. E. Sudaria \& D. C. Suministrado*
}

\begin{abstract}
The experiment was conducted to determine the (1) cracking, shearing, bending and tensile stresses of coconut shell at different positions of dehusked mature nut; (2) hardness of the coconut shell at different positions of dehusked mature nut; and (3) cracking streBB Of the dehusked mature coconut at different positions.

The range values of the parameters under study were as follows: cracking stress of the coconut shell, 3,345, 083.2-5, 397, $828.3 \mathrm{~kg} / \mathrm{m}^{2}$; shearing stress of coconut shell, 574,984.9-1, 258,830.9 $\mathrm{kg} / \mathrm{m}^{2}$; bending stress of the coconut shell, 1,775,213.1- 23,463,299.9 kg/m ${ }^{2}$, tensile stress of the coconut shell, $61,801.9-259,003.3 \mathrm{~kg} / \mathrm{m}^{2}$, hardness of the coconut shell, 150C51.5-150C57.6; and the cracking stress of the dehusked mature nut, $280,104.0-440,277.7 \mathrm{~kg} / \mathrm{m}^{2}$.

The combined average stresses on bending, shearing, tensile, cracking of coconut shell, and cracking of dehusked mature nut revealed no significant difference on stresses at any positions of the dehusked mature nut. This suggests that nuts could be splitted at any position without significant difference on power expenditure. For the design of the splitter machine, cracking stress of the coconut shell should be viewed very well since this parameter had the highest stress.
\end{abstract}

\section{INTRODUCTION}

One of the factors that affects the magnitude of a pro-fit in an entrepreneural activity is mechanization. Through mechanization, the input cost or the cost of production is lessened. To accomplish a certain activity by manual means costs more than by using appropriate machine to do it.

There is a big chance to mechanize the copra processing. Activities potential for mechanization are: dehusking, splitting, drying, scooping and chopping. Before a designer can effectively design any one of the processes above, he should consider the factors that will affect the design. One of the most important factors is the mechanical properties of the coconut. In engineering design, knowledge on the mechanical properties of the materials to be handled is very important for a successful design of a machine et al, 1976; Conge, 1983; Ghate et al, 1975; McRandal et al, 1980; Mensah et al, 1984; Mohsenin, 1970, 1972, 1977; Silberstein et al, 1977; Suggs et al, 1965; Wang et al, 1970; and Young et al, 1967.)

*Professors, Visayas State College of Agriculture, Baybay, Leyte and the UP at Los Banos, College, Laguna, respectively 
In some countries of the world dehusking is already mechanized. The next activity that could be mechanized js splitting the dehusked nuts. In the design of a mechanical splitter, the mechanical properties of the dehusked nut should be known as guide to the designers. The machine members could be designed enough to withstand the load for safety and economic reasons. A knowledge on the mechanical properties at the different positions of the dehusked mature nut dictates the orientation where to strike the blade of the splitter for reasonable power expenditure. The softer side or portion of the dehusked mature nut is the recommended point on which to strike the implement since it requires less energy to split the nut. Hence, the study was conducted to determine the (a) cracking, shearing, bending and tensile stresses of the coconut Bhell at the different positions of dehusked mature nut; (b) hardness of the coconut shell at the different positions of dehusked mature nut, and (c) cracking stress of the dehusked mature nut at different positions.

\section{MATERIALS AND METHODS}

The mature nuts with brown color which have a rattling sound when shaken from each palm. Thirty five pieces gathered randomly from different palms with the same variety were put together in a shed. one hundred five mature nuts from three varieties were collected and piled in the shed separately according to variety.

A two-factor factorial experiment in Complete Randomized Design was used. There were three coconut varieties and five/seven treatments replicated three times. The three coconut varieties were Baybay Tall, Yellow Malayan Dwarf and Albuera Dwarf. The treatments were apex, between apex and equator, equator, between base and equator and base.

The nuts were duhusked using the common dehusking tool which was a plow share mounted inadvertently on a wood with a stable base. The dehusked nut was oriented in all experiments by facing the base up with one live eye facing the person handling the dehusked nut. The nut was marked using chalk at the center of the base, center in between the equator and the base at left side of the person handling, center of the equator directly facing the person handling, center in between the equator and the apex at the right side of the person handling and at the center of the apex (Fig. 1). Five treatments only were applied for hardness and cracking stresses of shell and cracking stress of dehusked mature coconut experiments. Five treatments (apex, between equator and apex, equator, between equator and base and base) were taken from only one dehusked nut and this represents one replication. Three dehusked nuts were randomly selected from the pile of nuts with specific variety. There were seven treatments (apex, between equator and apex, transverse equator, diagonal equator, longitudinal equator, between equator and base and base) for tensile, shearing and bending stresses experiments. Three dehusked nuts represented one replication in tensile, shearing and bending experiments. The shell specimens were taken out from the marked dehusked nut using hack Baw for hardness, tensile, shearing, bending and cracking stresses of coconut shell experiments. The size of the shell specimens was $40 \mathrm{~mm} \times 40 \mathrm{~mm}$ for hardness and cracking stresses of coconut shell experiments; $20 \mathrm{~mm}$ x $40 \mathrm{~mm}$ for tensile and shearing stresses and $40 \mathrm{~mm} \times 60 \mathrm{~mm}$ for bending stress. The chalk mark on the shell was always the center of the shell specimens sawed. The fibers, coir dust and other foreign materials were removed from the sawed shell specimens using the knife.

The Shimadzu Universal Testing Machine was used to determine the cracking stress of dehusked nut, tensile, shearing, bending and cracking of coconut shell. The hardness of the shell was determined using the Rockwell Hardness Tester. 


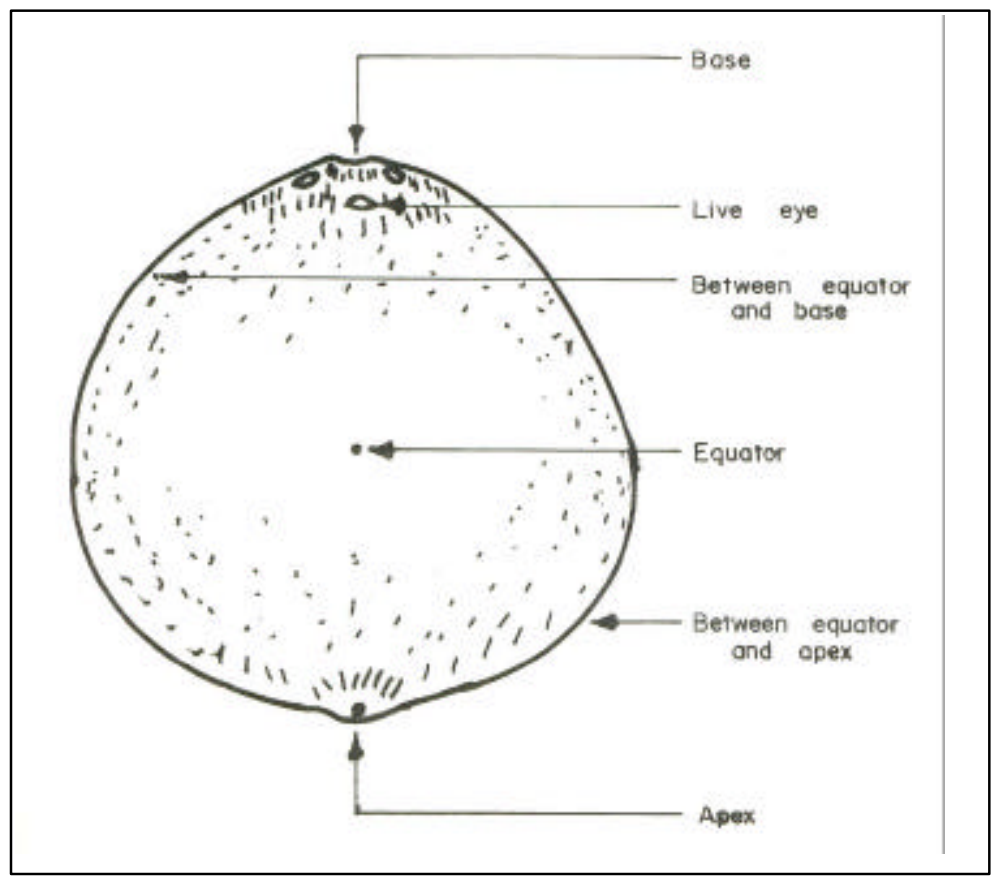

Fig. 1. The position of dehusked mature nut in locating the center of the shell specimen.

\section{RESULTS AND DISCUSSION}

The coconut shell failed abruptly without previous yield or permanent deformation. Like other brittle materials, the coconut shell has no yield point stress but instead, it yields ultimate stress directly. It coincided with the property of the brittle material.

\section{A. Cracking stress of the coconut shell at different positions of dehusked mature nut}

There was highly significant difference of cracking stresses at different positions of dehusked mature nut. The position between the equator and the base had the highest cracking stress (Table 1).

Table 1. Cracking stress of coconut shell at different positions of debusked mature nut $\left(\mathrm{kg} / \mathrm{m}^{2}\right)$

Treatment Mean*

Apex

Between equator and apex

Equator

Between equator and base

Base

$\begin{array}{ll}3,655,612.2 & \text { cd } \\ 3,345,083.2 & \text { d } \\ 4,096,294.6 & \text { bc } \\ 5,397,828.3 & \text { a } \\ 4,347,405.7 & \text { b }\end{array}$

*Treatment means followed by the same letter are not significantly different from each other at 5\% DMRT level of significance.

Its stress varied significantly over the other. This means that the position of the dehusked nut between the equator and the base was the hardest, therefore required more force to crack. On the other 
hand, between the equator and the apex, the shell easily cracked because the cracking stress was the lowest among the treatments. However, its cracking stress was not significantly different from apex although the value of the latter was higher.

There was significant difference of cracking stresses also among coconut varieties. Baybay Tall and Albuera Dwarf had the highest and lowest cracking stresses, respectively (Table 2).

Table 2. Cracking stress of the coconut shell 2 as affected by Varieties $(\mathrm{kg} / \mathrm{m})$

\begin{tabular}{ll} 
Variety & Mean* \\
\hline Baybay Tall & $4,939,745.0 \mathrm{a}$ \\
Yellow Malayan Dwarf & $4,247,951.5 \mathrm{~b}$ \\
Albuera Dwarf & $3,317,637.8 \mathrm{~b}$ \\
-
\end{tabular}

*Variety means followed by the same letter are not significantly different from each other at 5\% DMRT level of significance.

This was possible because Baybay Tall was observed to have thicker shell than Albuera Dwarf nuts. the development seemed proportional' thicker shell for larger nut and thinner shell for smaller nut.

There was no interaction effect between the treatment and variety. Baybay Tall had the highest cracking stress at the position between equator and base.

\section{B. Hardness of coconut shell at different positions of dehusked mature nut}

There was no significant difference of hardness of coconut shell among treatments of dehusked mature nut. the non-significance of hardness among treatments suggested the similarity of the shell hardness at different positions of dehusked nut. The hardness of the coconut shell ranged from 150C51.1 to 150C57.6 Rockwell Hardness (Table 3). The equator and the base had the highest and lowest values, respectively. The equivalent hardness of the coconut shell using $10 \mathrm{~mm}$ carbide ball with $3,000 \mathrm{~kg}$ load of the Brinell.

Table 3. Hardness of the coconut shell at different positions of dehusked mature nut (150C)

\begin{tabular}{lc}
\multicolumn{1}{c}{ Treatment } & Mean \\
\hline Apex & 53.8 \\
Between equator and apex & 54.4 \\
Equator & 57.6 \\
Between equator and base & 57.4 \\
Base & 51.1 \\
\hline-----------
\end{tabular}

Hardness Number (BHN) ranged from 497 to 606 BHN (Mantell, 1958). The hardneSB Of the shell is within the range of the hardness of high-strength steel. According to Shigley et al (1983), the hardness of the high-strength steel ranged from 380 to $705 \mathrm{BHN}$. 
There was highly significant difference of hardness among varieties. Yellow Malayan Dwarf and Baybay Tall had the highest and lowest values, respectively (Table 4).

\section{Tensile stress of coconut shell at different positions of dehusked mature nut}

Differences on tensile stresses of coconut shell at different positions of dehusked mature nut significantly varied from each other. Base had the highest tensile stress over the others (Table 5).

Table 4. Hardness of the coconut shell at different coconut varieties $(150 \mathrm{C})$

\begin{tabular}{ll}
\hline Variety & Mean* \\
\hline Baybay Tall & $51.9 \mathrm{~b}$ \\
Yellow Malayan Dwarf & $59.4 \mathrm{a}$ \\
Albuera Dwarf & $53.2 \mathrm{~b}$ \\
\hline
\end{tabular}

*Variety means followed by the same letter are not significantly different from each other at 5\% DMRT level of difference.

Table 5. Tensile stress of coconut shell at different positions of Dehusked mature nut $(\mathrm{kg} / \mathrm{m} 2)$

\begin{tabular}{lll} 
Treatment & Mean* & \\
\hline Apex & $136,118.3$ & ab \\
Between equator and apex & $126,553.1$ & $\mathrm{ab}$ \\
Transverse equator & $256,605.2$ & $\mathrm{a}$ \\
Diagonal equator & $219,240.3$ & $\mathrm{a}$ \\
Longitudinal equator & $123,137.3$ & $\mathrm{ab}$ \\
Between equator and base & $61,801.9$ & $\mathrm{~b}$ \\
Base & $259,003.3$ & $\mathrm{a}$ \\
-
\end{tabular}

*Treatment means followed by the same letter are nOt Bignificantly different from each other at 5\% DMRT level of significance.

Transverse, diagonal and longitudinal equators did not vary significantly from each other. Their values were comparable although they differed a little. There was no significant effects of tensile stress among varietieB and interaction between treatment and variety.

\section{Shearing stress of coconut shell at different positions of dehusked mature nut}

There was significant difference among varieties and the interaction between treatment and variety. Apex had the highest shearing stress among treatments. Shearing stress of apex, between equator and apex, transverse equator and diagonal equator did not vary significantly to the longitudinal equator, between equator and base and base. Transverse, diagonal and longitudinal equators did not vary significantly from each other (Table 6). 
Shearing stress among varieties significantly varied from each other. Baybay Tall and Yellow Malayan Dwarf had similar shearing stress. They did not vary significantly from each other. However, Albuera Dwarf varied significantly from Baybay Tall and Yellow Malayan Dwarf (Table 7).

Table 6. Shearing stress of the coconut shell at different positions of dehusked mature nut $(\mathrm{kg} / \mathrm{m} 2)$

\begin{tabular}{lrl}
\multicolumn{1}{c}{ Treatment } & Mean* & \\
\hline Apex & $1,258.830 .9$ & $\mathrm{a}$ \\
Between equator and apex & $1,196,216.5$ & $\mathrm{a}$ \\
Transverse equator & $1,017,017.5 \mathrm{ab}$ \\
Diagonal equator & $872,066.3 \mathrm{ab}$ \\
Longitudinal equator & $574,984.9 \mathrm{~b}$ \\
Between equator and base & $701,987.1 \mathrm{~b}$ \\
Base & $686,778.3$ & $\mathrm{~b}$
\end{tabular}

*Treatment means followed by the same letter are not significantly different from each other at 5\% DMRT level of difference.

Table 7. Shearing stress of the coconut shell as affected by variety $(\mathrm{kg} / \mathrm{m} 2)$

\begin{tabular}{lr}
\multicolumn{1}{c}{ Variety } & \multicolumn{1}{c}{ Mean* } \\
Baybay Tall & $95,060.5 \mathrm{~b}$ \\
Yellow Malayan Dwarf & $80,823.8 \mathrm{~b}$ \\
Albuera Dwarf & $2,527,493.5 \mathrm{~b}$ \\
\hline
\end{tabular}

*Variety means followed by the same letter are not significantly different from each other at 5\% DMRT level of significance.

There was an interaction. effect between the treatment and the variety. Some treatments/positions like apex, between equator and apex, transverse equator, diagonal equator, longitudinal equator and between equator and base did not significantly vary from each other and in two varieties (Baybay Tall and Yellow Malayan Dwarf). However, Baybay Tall and Yellow Malayan Dwarf varied significantly from Albuera Dwarf. only apex varied significantly in each three varieties (Table 8).

\section{E. Bending stress of the coconut shell at different positions of dehusked mature nut}

There was highly significant difference of bending stress of coconut shell at different positions of dehusked mature nut. Different parts of the dehusked nut had different bending stresses. 
Table 8. Interaction effect between position and variety on the shearing stress of coconut shell $(\mathrm{kg} / \mathrm{m} 2)$

\begin{tabular}{|l|r|r|r|}
\hline \multirow{2}{*}{\multicolumn{1}{c|}{ Treatment }} & \multicolumn{3}{|c|}{ Variety mean } \\
\cline { 2 - 4 } & $\begin{array}{c}\text { Baybay } \\
\text { Tall }\end{array}$ & $\begin{array}{c}\text { Yellow } \\
\text { M'yan dwarf }\end{array}$ & $\begin{array}{c}\text { Albuera } \\
\text { dwarf }\end{array}$ \\
\hline Apex & $139,415.0 \mathrm{e}$ & $77,386.4 \mathrm{e}$ & $3,559,691.4 \mathrm{a}$ \\
\hline Between equator \& apex & $88,672.8 \mathrm{e}$ & $70.271 .5 \mathrm{e}$ & $3,429,705.2 \mathrm{a}$ \\
\hline Transverse equator & $98,580.2 \mathrm{e}$ & $105,249.9 \mathrm{e}$ & $2,847,222.2 \mathrm{ab}$ \\
\hline Diagonal equator & $69,753.1 \mathrm{e}$ & $44,532.6 \mathrm{e}$ & $2,501,913.3 \mathrm{bc}$ \\
\hline Longitudinal equator & $491,101.4 \mathrm{de}$ & $50,463.0 \mathrm{e}$ & $1,625,390 . \mathrm{c}$ \\
\hline Between equator \& base & $110,024.2 \mathrm{e}$ & $108,669.1 \mathrm{e}$ & $1,887,267.9 \mathrm{c}$ \\
\hline Base & $109,876.5 \mathrm{e}$ & $1,099,194.3 \mathrm{~d}$ & $1,841,264.2 \mathrm{c}$ \\
\hline
\end{tabular}

*Means followed by the same letter are not significantly different from each other at 5\% DMRT level of significance.

There was no significant difference of bending stress among varieties and the interaction between treatment and variety. Table 9 shows the mean bending stress of the different positions. Between the equator and apex gave the highest bending stress. The bending stresses of base and between equator and base were not significantly different from each other. The bending stress between the equator and base varied significantly to all treatments except the base.

\section{F. Cracking stress of dehusked mature coconut}

The cracking stress of dehusked mature coconut was highly significant among treatments, varieties and interaction between treatment and variety. Between equator and base and between equator and apex had the highest and lowest cracking stresses, respectively.

Table 9. Bending stress of the coconut shell at different positions of dehusked mature nut $(\mathrm{kg} / \mathrm{m} 2)$

\begin{tabular}{lll}
\multicolumn{1}{c}{ Treatment } & Mean* & \\
\hline Apex & $1,826,495.8$ & $\mathrm{~d}$ \\
Between ecluator and apax & $1,775,223-2$ & $\mathrm{a}$ \\
Transverse equator & $2,615,740.7$ & $\mathrm{~b}$ \\
Diagonal equator & $2,514,351.9$ & $\mathrm{bc}$ \\
Longitudinal equator & $1,961,798.4$ & $\mathrm{~cd}$ \\
Between equator and base & $3,463,299.9$ & $\mathrm{a}$ \\
Base & $2,937,216.6$ & $\mathrm{ab}$
\end{tabular}

*Treatment means followed by the same letter are not significantly different from each other at 5\% DMRT level of significance.

The value between equator and apex was comparable to the value of the equator since they did not differ significantly (Table 10). 
Table 10. Cracking stress of dehusked mature coconut at different positions $(\mathrm{kg} / \mathrm{m} 2)$

\begin{tabular}{|c|c|c|}
\hline Treatment & Mean* & \\
\hline Apex & $356,370.3$ & $\mathrm{bc}$ \\
\hline Between equator and apex & $280,104.0$ & $\mathrm{~d}$ \\
\hline Equator & $393,266.3$ & $\mathrm{ab}$ \\
\hline Between equator and base & $440,277.7$ & $\mathrm{a}$ \\
\hline Base & $329,953.6$ & $\mathrm{~cd}$ \\
\hline
\end{tabular}

*Treatment means followed by the same letter are not significantly different from each other at 5\% DMRT level of significance.

The cracking stress of Baybay Tall and Yellow Malayan Dwarf did not significantly vary from each other. Yellow Malayan Dwarf significantly varied from Albuera Dwarf. Albuera Dwarf did not vary significantly from Baybay Tall (Table 11).

Table 11. Cracking stress of dehusked mature coconut as affected variety $(\mathrm{kg} / \mathrm{m} 2)$

\begin{tabular}{|c|c|}
\hline TREATMENT & MEAN* \\
\hline Baybay Tall & $372,758.8 \mathrm{ab}$ \\
\hline Yellow Malayan Dwarf & $409,567.5 \mathrm{a}$ \\
\hline Albuera Dwarf & $297,656.9 \mathrm{~b}$ \\
\hline
\end{tabular}

*Variety means followed by the same letter are not significantly different from each other at 5\% DMRT level of significance.

Baybay Tall had the highest cracking stress on its shell but second only in terms of cracking stress of husked nut. This could be possible because of the influence of the meat to the cracking activity. It could be interpreted based from results that Yellow Malayan Dwarf had harder or thicker meat than Baybay Tall.

There was highly significant interaction between the treatment and variety. Cracking stress between the equator and the base which had the highest value was significant in Baybay Tall and Yellow Malayan Dwarf. However, they varied significantly from Albuera Dwarf. Other treatments like apex and between equator and apex did not vary significantly in three varieties (Table 12).

Table 12. Interaction effect between the position and variety on the cracking stress of dehusked mature coconut $(\mathrm{kg} / \mathrm{m} 2)$

\begin{tabular}{|l|r|r|r|}
\hline \multirow{2}{*}{ Treatment } & \multicolumn{3}{|c|}{ Variety Mean } \\
\cline { 2 - 4 } & $\begin{array}{c}\text { Bayab } \\
\text { Tall }\end{array}$ & $\begin{array}{c}\text { Yellow } \\
\text { M'yan Dwarf }\end{array}$ & $\begin{array}{c}\text { Albuera } \\
\text { Dwarf }\end{array}$ \\
\hline Apex & $319,183.2 \mathrm{cdef}$ & $339.705 .2 \mathrm{cde}$ & $410,222.4 \mathrm{abcde}$ \\
\hline Between equator \& apex & $298,442.8 \mathrm{def}$ & $313,633.6 \mathrm{def}$ & $229,235.5 \mathrm{ef}$ \\
\hline Equator & $437,730.7 \mathrm{abc}$ & $491,873.9 \mathrm{ab}$ & $250,194.3 \mathrm{ef}$ \\
\hline Between equator \& base & $410,877.4 \mathrm{abcd}$ & $530,079.8 \mathrm{a}$ & $379,876.0 \mathrm{bdc}$ \\
\hline Base & $397,559.9 \mathrm{bcd}$ & $373,544.7 \mathrm{bcd}$ & $218,756.2 \mathrm{f}$ \\
\hline
\end{tabular}

*means followed by the same letter are not significantly different from each other at 5\% DMRT level of significance. 


\section{RECOMMENDATION}

Based from the results of thiS Btudy, dehusked nuts could be splitted at any positions with no significant power expenditure among each other. However, in the design of a machine member, the highest value which was $5,397,828.3 \mathrm{~kg} / \mathrm{m}^{2}$ at between the equator and base of the cracking stress of the coconut shell should be considered. Of all the stresses combined, cracking stress had the largest stress value. For a person who will design a mechanical coconut husk splitter, he should take a closer look on the cracking stress of the shell since this will affect the design of the machine.

\section{REFERENCES}

ANAZODO, U. G. N. 1983. Mechanical Properties of the Corn Cob in Simple Bending. Transactions of the American Society of Agricultural Engineers. General Edition. July-August Vol. 26 No.4 pp. 1229-1233.

BAKER, J. T. AND C. G. HAUGH. 1979. Mechanical Properties of Bone: A Review. Transactions of the American Society of Agricultural Engineers. General Edition. May-June. Vol. 22 No. 3. pp. 678-687.

BASHFORD, L. L., J. W. MARANVILLE, S. A. WEEKS and R. CAMPBELL. 1976. Mechanical Properties Affecting Lodging of Sorghum. Transactions of the American Society of Agricultural Engineers. General Edition.September-October Vol.19 No.5 pp.962-966.

CONGE, A. D. 1983. Mechanical Properties of Coconut Husk at Three Maturity Levels. Master's Thesis in Agricultural Engineering. University of the Philippines at Los Banos, College, Laguna.

GHATE, S. R. and R. P. ROHRBACK. 1975. Mechanical Properties Influencing Vibrations in Blueberry Canes. Transactions of the American Society of Agricultural Engineers. General Edition. September-October. Vol.18 No.5. pp.921-925.

MANTELL, C. L. 1958. Engineering Materials Handbook. First Edition. McGraw-Hill Book Company. New York pp.1-30.

MCRANDAL, D. M. \& P. G. MCNULTY, 1980. Mechanical and Physical Properties of Grasses. Transactions of the American Society of Agricultural Engineers. General Edition. July-August. Vol. 23 No.4 pp. 816-821

MENSAH, J. K., G. L. NELSON, F. L. HERUM and T. G. RICHARD. 1984. Techanical Properties Related to Soybean Seedcoat Cracking During Drying. Transactions ofthe American Society of Agricultural Engineers. General Edition. MarchApril Vol. 27 No. 2 pp. 550-555.

MOHSENIN, N. N. 1977. characterization and Failure in Solid Foods with Particular Reference to Fruits and Vegetables. J. Texture StudieB. Vol.8 pp. 169-193.

1972. Mechanical Properties of Fruits and Vegetables Review of a Decade of Research Applications and Future Needs. Transactions of the American Society of Agricultural Engineers. General Edition. November-December Vol. 15 No.6 pp.1064-1070.

1970. Physical Properties of Plant and Animal Materials. Gordon and Breach Science Publishers, New York. Vol. 1 
SHIGLEY, J. E. and L. D. MITCHELL. 1983. Mechanical Engineering Design. Fourth Edition. McGraw-Hill Book Company. New York. pp. 823-824

SILBERSTEIN, D. A. and V. N. M. RAO. 1977. Mechanical Properties of Peanuts at Various Temperatures and Relative Humidities. Transactions of the American Society of Agricultural Engineers. General Edition. July-August. Vol.20 No.4 pp. 746-748.

SUGGS, C. W. and W. E. SPLINTER. 1965. Mechanical Properties of Tobacco Stalks. Transactions of the American Society of Agricultural Engineers. General Edition. Vol. 8 No. 3. pp. 361-364.

WANG, J.K. and H.S. CHANG. 1970. Mechanical Properties of Papaya and Their Dependence on Maturity. Transactions of the American Society of Agricultural Engineers. General Edition. May-June Vol.13 No. 3 pp. 369-371.

YOUNG, R.E. and C.W. SUGGS. 1967. Physical Properties of Tobacco Stalks Part II. Module of Tension and Compression and Hysteresis Characteristic of Woody Tissue of Tobacco Stalks, Tobacco Science. Vol. 2. pp. 163-167. 